\title{
Chapter One: The Role of Government in a Modern Market Economy
}

Public finance is the study of the goods and services provided through the public sector and their financing. Countries around the world face similar challenges in determining what activities their governments should pursue and how these activities should be financed. Economists have thought long and hard about this issue. Thus, it is useful to begin the study of public finance by reviewing how economists view the appropriate role of government in a modern market economy.

\subsection{The Economic Justification for Government Activity}

Non-economists with conservative political leanings sometimes argue that government has only two legitimate functions: providing public safety and order (military and police service, with related court activities) and foreign relations. Classic socialists, in contrast, traditionally believe that government should undertake most, if not all, economic activities in a country and own the bulk of all resources. For most economists, the justification for government rests on market failure: the belief that various imperfections will make private markets unable to supply all goods and services people want in an optimal fashion and that government can improve the outcome by addressing these imperfections. 


\subsubsection{Conditions for private markets to yield an optimal allocation of goods and services}

Economic theory states that, if certain critical assumptions are satisfied, private markets should provide an optimal allocation of goods and services. The key assumptions are as follows:

1. A market exists for every good and service.

2. Every market is characterized by perfect competition, meaning that no individual or small group of agents has the power to influence prices.

3. Everyone in each market has ready access to the same information ("everyone knows what anyone in the market knows").

4. Contract negotiation and enforcement have negligible costs.

5. Production functions exhibit decreasing returns to scale in production, meaning that, beyond some point, the cost per unit of production of every good or service begins to rise. (This makes it efficient to have more than one producer of each item.)

6. There are no externalities, meaning that the production and/or consumption of an item by one party will not affect the well-being of those not producing or consuming it.

7. Producers can prevent those who do not pay for goods from having access to them. In other words, there are no goods for which, if one person has access to them, everyone does.

Besides these seven assumptions, some would add an eighth: that people have similar preferences (and similar welfare functions).

\subsubsection{Consequences of market imperfections}

What happens if the above assumptions are violated?

1. Not all goods have ready markets. For example, private insurers may be unwilling to provide health insurance for all individuals without restrictions, because the required premiums will drive away healthy 
customers, and only the sick (who will impose high costs) will pay. Economists call this situation "adverse selection."

2. Many markets are characterized by imperfect competition, in which there are few enough buyers or sellers that some have the power to influence the price of what is bought and sold. In this case, the market price will typically exceed marginal cost, distorting the allocation of resources, as some people buy (or sell) less than they would like if the market were competitive and price equaled marginal cost. A monopolist, for example, raises the market price of an item above marginal cost, causing less to be purchased than in a perfectly competitive market.

3. Imperfect information characterizes many markets, particularly in the financial sector. In these markets the more knowledgeable party can extract abnormal profits from others, raising costs, reducing sales, and again distorting the allocation of resources. Shrewd doctors, for example, can order unnecessary tests and services if not subject to review, while clever financiers can hide information from the public if not supervised. In extreme cases, the information imbalance makes it hard for a market to function. For example, purchasers of used cars may worry that the only cars offered are "lemons," thereby driving down market valuations and discouraging owners of "good" cars from offering them for sale. ${ }^{1}$

4. Contract negotiation and enforcement are usually costly. While private arbitration can resolve some claims, courts of law may be needed to resolve conflicts peaceably.

5. A few services, such as electricity generation, landline telephone service, and railroads, exhibit steadily decreasing average costs, because the marginal cost of supplying another customer is very low and overhead costs are virtually fixed, up to the capacity of the system. For such items, markets will tend toward monopoly, and monopoly

1This is the classic "market for lemons" problem first discussed by George Akerlof. See Akerlof, G. A. (1970), "The Market for 'Lemons': Quality Uncertainty and the Market Mechanism," Quarterly Journal of Economics, vol. 84(3), pp. 488-500. 
prices will prevail unless government supplies the item itself or regulates the behavior of a private monopoly supplier.

6. Many goods have externalities, either negative or positive. On the negative side, for example, the production of many items generates waste and pollution, while every car on a crowded highway contributes to congestion. Many other items have positive externalities. For example, basic research provides unknown benefits that others can tap through commercialization, while public vaccination programs protect everyone by reducing the incidence of communicable diseases. If left solely to the market, people may find themselves with too much pollution and congestion, because those generating the negative externalities will not bear the costs they impose on others. Likewise, there may be too little basic research, and too few people will find it worthwhile bearing the cost of being vaccinated.

7. A few goods have the characteristic that, if anyone has access to them, everyone does, even those who have not paid for them. For example, everyone in a community benefits from an effective police force and court system that contribute to a low-crime environment, whether or not they pay taxes. Likewise, a strong and properly functioning military protects all of a country's citizens. Because it is hard to exclude those who have not paid for such goods, private firms will have difficulty producing them.

8. Sellers may have incentives to engage in market manipulation, providing misleading information that distorts consumer choices what Akerlof and Shiller call "phishing". 2

Besides the above considerations, markets may not yield a politically acceptable distribution of income and wealth. Differences in skills, combined with consumer preferences, can allow for widespread poverty and substantial inequality of income and wealth. In addition, private insurance may be unavailable to help individuals cope with severe income loss during economic downturns. Massive inequality may inhibit the free and voluntary exchange required for markets to work

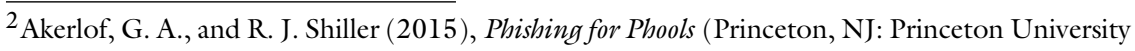
Press), p. xi. 
well. It may also have undesirable political consequences, giving far greater political access to the wealthy than to others and possibly undermining the support for democracy as a consequence.

Finally, markets can experience large swings - pronounced business cycles and large booms and busts in asset markets - if left unattended. The high resulting costs can justify government stabilization efforts.

Because the key assumptions do not characterize reality, most economists would argue that there is an economic case for government, even in a market economy. Governments should do what markets cannot. From an economic perspective, governments should devote effort to the following (see Figure 1.1):

1. Address externalities

2. Address monopolies, natural and otherwise

3. Provide public goods

4. Address information failures

5. Provide macroeconomic stabilization

6. Provide social safety nets, to address concerns about the distribution of income

7. Provide a supportive legal framework and other services needed for markets to operate effectively

Figure 1.1. Key tasks for government in a market economy.

1. Address externalities. Governments should use their powers to tax and subsidize, or regulate (prohibit or compel), activities, to limit negative externalities such as pollution and congestion and stimulate the production of more goods with positive externalities, such as public health and basic research, than private markets will create on their own. Taxing negative externalities and subsidizing positive externalities are the best ways to do this, because they internalize to the producer and consumer the external costs and benefits of their actions. This approach allows the populace to determine how much of these goods and services is produced, through the interaction of supply and demand in markets, because the taxes and subsidies are factored into costs and prices. 
When taxes and subsidies are infeasible, regulation may be necessary. However, regulation, which appeals instinctively to noneconomists, is often less desirable, because it imposes fixed limits on the offending (or desirable) items, rather than letting the interaction of people's preferences in markets determine how much of the items is produced or consumed. ${ }^{3}$

2. Address monopolies. Because monopolies impose heavy social costs, governments should either (a) acquire and operate them, to secure the optimal outcome (setting price at marginal cost, possibly with some charge for overhead) or (b) regulate them, letting a private owner produce the good or service but setting the price at a socially desirable level (cost-covering, plus a modest profit margin).

3. Provide public goods. Government needs to ensure an adequate supply of basic infrastructure (roads, highways, clean water and sewage services), military and police protection, judicial services, public health services, and the like, because difficulties in pricing and excluding those who do not pay (what economists call "free riders") will make it hard for the private sector to provide these goods in adequate quantities. Whether education is a public good raises separate issues (Box 1.1).

4. Address information failures. It usually takes a government to intervene and correct information failures, since those benefiting will not want to correct them. Self-regulation is notoriously ineffective and often makes a bad situation worse (for example, guilds frequently create cartels, and doctors are typically loath to punish one of their own). At the same time, those who are hurt may benefit too little as individuals to finance the necessary oversight services, or they may lack the power to contend effectively with those disseminating misleading information. These reasons explain why many economists who oppose other government activities favor appropriate government regulation and supervision of the financial sector (which also provides a public good). It also gives

\footnotetext{
${ }^{3}$ For a classic analysis of this issue, comparing the costs and benefits of using taxes and subsidies, rather than regulation, see Schultze, C. (1977), The Private Use of Public Interest (Washington: Brookings Institution).
} 
a justification for a government to compel people to save for their retirement, since an inherent focus on the short term will cause many young people to save too little voluntarily.

Besides the above four concerns, the shortcomings of markets justify three other government activities: stabilization, creating appropriate social safety nets, and providing a supportive legal and regulatory framework for private markets.

5. Stabilize the economy. Experience shows that markets are subject to wide swings that individuals have no incentive to address through counter-cyclical behavior. When times are good, people usually benefit by borrowing and investing in the expectation of everhigher profits, or assuming that prices of stocks and other assets will continue to rise. Absent perfect foresight, there is little gain for individuals to act contrarily and limit the excesses of over-optimism. Likewise, in a recession, when the economy looks bleak, individuals have little to gain by taking a risk and investing, since there is no assurance that the economy will turn around. In these situations, government intervention (through monetary and fiscal policies) can cool an overheated economy or provide new demand to a weak one (by lowering interest rates, cutting taxes, and increasing government spending). This is an argument against requiring a balanced budget every fiscal year, at least at the central government level. However, as noted in Chapter 14, a less restrictive fiscal rule, such as a ceiling on the government's debt-to-GDP ratio or a requirement that the government balance its budget over the business cycle, may have benefits, particularly if some flexibility is allowed during severe recessions.

6. Create a social safety net. Market economies will not automatically create what most people consider a just distribution of income and assets. People whose skills are highly valued and in short supply will earn high incomes, while those with few marketable skills will earn little, if anything. Moreover, the distribution of income also reflects the initial distribution of wealth and power, which can be highly unequal. For this reason, there is usually support for measures to narrow the gaps left by the market. At a minimum, most societies provide at least a modicum of support for the poor and disabled. 
Wealthier societies often do more, providing such social services as highly subsidized access to basic health care, child care, and services for the elderly. Most but not all also provide benefits for the unemployed, to reduce the costs of involuntary joblessness. In addition, many societies try to reduce inequities of wealth by taxing estates and inheritances and use progressive income taxes to lessen the inequality of income. Different countries have different views on these issues, with the extent of the safety net varying from one nation to another.

7. Provide a supportive legal framework and other services for markets. It is hard for markets to work properly without a supportive legal framework, including the enforcement of property rights. Individuals will be reluctant to produce and invest if others can steal their property or wrest control of the companies they have built or purchased. Hence, government can play a key role by providing effective legal enforcement of property rights, including protections for intellectual property (patents and trademarks). Government protection of creditors' rights, through the courts and bankruptcy procedures, is important to support banking, while government support for the rights of minority shareholders may be critical to promote stock markets and the widespread ownership of company shares.

To be sure, government activity comes at a price, so the costs of government activity must be considered alongside the benefits.

\section{Virtually any government action interferes with the outcome of} private markets. Taxation changes prices. Subsidies affect people's incentives about purchases and spending. Regulation either compels or prohibits activity, limiting freedom of action. All of these distort markets.

2. Government action imposes financial costs and administrative burdens. Workers are needed to carry out government programs, and budgets are required to pay for them and the cost of any materials and supplies needed for workers to do their jobs. In addition, private individuals and firms bear the cost of paying 
taxes and complying with any rules associated with government programs. Heavy regulation or taxation can prohibit useful private activity, while corruption can raise costs, reduce investment, and curb growth.

Thus, it is important that the benefits from government activity outweigh these costs.

\subsection{Specific Activities for Governments}

\subsubsection{Addressing natural monopolies}

Natural monopolies arise when the identified fixed costs and a low marginal cost of accommodating another customer lead to declining marginal and average costs of service. In this situation, provision by a single entity is the most efficient way to supply the service. Electricity generation and distribution and landline telephone service are common examples of natural monopolies.

As shown in Figure 1.2, a monopolist can be expected to choose a market price at the level of output where marginal cost equals marginal revenue. When the demand curve slopes downward, the market price will exceed marginal revenue, and the monopolist earns a profit indicated by the area between the demand curve and the average cost curve for each unit sold. Because market price exceeds marginal revenue, consumers opt for less of the item than they would in the more optimal case where price equals marginal cost. In such a situation the government can intervene and improve consumer welfare, either by operating the company and setting price at marginal cost or by imposing a similar regulation on the existing private supplier. Because average cost exceeds marginal cost, the government must offset the loss with a budgetary transfer (at the expense of taxpayers) or set price at average cost (which yields a second-best result). In the case of private utilities, many governments set the market price such that the company can earn a modest but appropriate rate of return on its capital. 


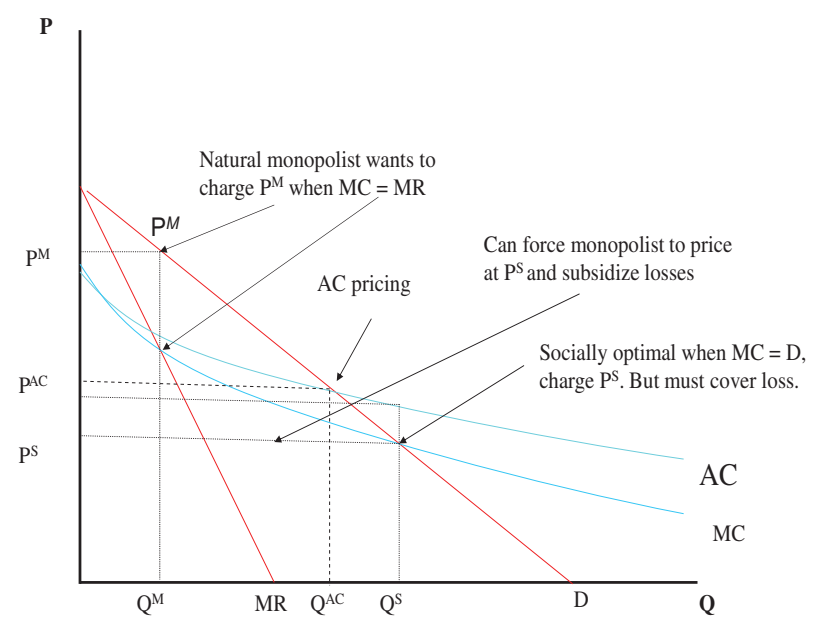

Figure 1.2. Natural monopoly pricing issues.

\subsubsection{Public goods}

As explained earlier, public goods have two main characteristics. First, they are what economists call "non-rival in consumption," meaning that many people can use them at the same time, and no one's consumption is reduced when another user is added. Second, the goods exhibit "non-excludability," meaning that it is hard to keep people from using them once they are available, even if they do not pay for them. This gives rise to what economists call the "free rider" problem, where people can get something without having to pay for it (Box 1.2). ${ }^{4}$ Because public goods are available to anyone, it is hard for private suppliers (who need to exclude those who don't pay from having access) to provide them. In addition, the social benefits from public goods will typically far exceed the private benefits to any single user, making it unattractive for any one user to bear the cost of providing them. Lighthouses, public parks, clean air, and an unspoiled environment are classic public goods, usually requiring either

\footnotetext{
${ }^{4}$ For a discussion of the free rider problem, see Hardin, R. (2008), "The Free Rider Problem", Stanford Encyclopedia of Philosophy (Fall Edition), at http://plato.stanford.edu/archives/ fall2008/entries/free-rider/.
} 
a government or a club of identified users (who force each person in the club to contribute) to finance them. A classic example is the socalled "tragedy of the commons," in which a common resource that no one owns will deteriorate from overuse unless government or a club of individuals agrees to enforce rules that maintain the resource. ${ }^{5}$ Similarly, a commonly used resource, such as a public park or fishing area, may deteriorate from overuse unless a government intervenes to provide maintenance and regulate usage. Proper valuation requires that the benefits and costs to every affected individual be summed, to see whether the collective benefit justifies the cost. ${ }^{6}$ Failure to do so can lead to undervaluing public goods and, hence, spending too little for them. Infrastructure spending in the United States may provide an example (Box 1.3).

\subsubsection{Creating an economic framework that allows private markets to work well}

Some public goods are important enough to be worth mentioning separately. One is creating an economic framework that allows private markets to work well. This involves three critical elements.

(1) Property rights. The first element is the enforcement of property rights. A key breakthrough in economic history was the acknowledgment by sovereigns that private firms could retain the bulk of the earnings from businesses. ${ }^{7}$ Without such assurances, firms are unlikely to invest. Indeed, experiences in Eastern Europe and the former Soviet Union during the 1990s have shown the chilling effects on foreign investment when investors find that companies

\footnotetext{
${ }^{5}$ The classic analysis is in Hardin, G. (1968), "The Tragedy of the Commons," Science, vol. 162, no. 3859, pp. 1243-1248; also at http://www.garretthardinsociety.org/articles/art_tragedy_ of_the_commons.html.

${ }^{6}$ See Samuelson, P. (1954), "The Pure Theory of Public Expenditure," Review of Economics and Statistics, vol. 36, no. 4, pp. 387-389.

${ }^{7}$ See, for example, Heilbroner, R., and L. Thurow (1998), Economics Explained (New York: Simon and Schuster), Chapter 1.
} 
or investments they have created or renovated can be taken over at will by local mafias.

(2) Effective judicial system. A second element is the creation of an honest and efficient judicial system. The World Bank lists the prompt and efficient resolution of commercial disputes as one of the important criteria for assessing a country's business climate. ${ }^{8}$ In many developing countries, the long time periods needed for commercial disputes to come to trial or perceptions that courts are biased have been serious impediments to foreign investment. Similarly, problems in the domestic court system led many foreign investors in Romania during the early 1990s to develop elaborate (and costly) provisions in contracts as a way of resolving commercial disputes. An efficient legal system is also critical for developing respect for the rule of law, including the recognition of contracts. Thus, an effective court system is a key aspect of economic development.

(3) Competitive markets. A third element involves measures to promote competitive markets. As noted earlier in this chapter, competitive markets are essential for consumers to achieve the benefits possible from a market economy. Monopoly, whether by sellers or buyers, restricts the opportunities available in markets and drives up prices. This in turn affects the allocation of resources, as consumers (or sellers, in the case of a monopoly buyer) change their buying or selling patterns in response to relative prices. By enacting anti-monopoly laws and taking other measures to promote competition (for example, opening markets to foreign suppliers), governments can help markets work better. Since government-owned firms may have "unfair advantages" relative to private producers, governments can also promote healthy competition by leaving most markets to private firms. ${ }^{9}$

\footnotetext{
${ }^{8}$ See World Bank, "Doing Business: Measuring Business Regulation," http://www. doingbusiness.org.

${ }^{9}$ For further discussion of state-owned enterprises, see Chapter 8.
} 


\subsubsection{Managing public goods and services}

Providing public goods and services raises certain management issues for the government, including financing, how much to supply, and the operation and maintenance of facilities.

Financing is perhaps the most fundamental management decision facing government provision of public services. Cost recovery is an option where the government can identify those actually using the goods. In this case, the government can finance the goods through user fees or special levies. Many bridges, roads, and public parks have tolls or entrance fees, for example. Similarly, in some countries the costs of public schooling or sanitation service are fully or largely covered by special taxes levied on those in the area receiving the service.

Optimal pricing theory would suggest basing prices on marginal costs. However, in the case of an item with flat or declining marginal costs, marginal cost pricing will fail to recover the fixed costs of providing the good. Unless the government subsidizes these costs through the budget, pricing at average cost (for cost recovery) offers a second-best alternative. If public facilities experience congestion, the government may want to use peak-period pricing, recovering the average cost of provision (including construction or capital costs) through a series of charges that are higher than average cost during busy periods and somewhat below average cost during periods of less use. Another option, which many private clubs follow, is to levy a twopart tariff that combines both a "cost of use" and a capital (or overhead) charge.

If users cannot be clearly identified, or if an item (such as primary education) has substantial positive externalities and user charges would be prohibitively expensive for many potential users, budget financing through taxation may be preferable. In this case, the taxpaying public bears the cost of provision, with individual burdens depending on the level and composition of taxes used to fund the government. Where users of the service can be identified, the government may choose to 
impose a combination of user charges and budget subsidies. In many countries, for example, tuition at government-run universities is set at modest levels, so that low-income students can attend. ${ }^{10}$ In this case, a substantial budget subsidy covers the remaining costs. Similarly, many government printing offices set the price of official publications at close to marginal cost and use general budget financing to cover the overhead expenses of the printing agency.

Closely related to the financing issue is how much to supply. In democracies, various methods are available to address this issue. Planning officials, for example, can propose the level of service based on certain criteria. Governments can also survey the public for information. In some cases, the public decides by voting. In the United States, for example, voters in many jurisdictions are asked at the time of state or national elections to vote on proposed bond issues whose proceeds are to be used to fund public facilities such as parks or schools. Elections themselves sometimes resolve the issue, as one party or set of candidates may favor one level (or allocation) of services, while another favors a different level or combination of services. Where budget financing is involved, the quantity of services also depends on the amount of revenue available. Governments with little revenue, or where existing budget responsibilities absorb virtually all the available funds, will be less able to finance expenditures than those with room to expand spending ("fiscal space"). Indeed, the level of service provision is often linked to decisions about taxation, with some voters favoring lower taxes and service levels and others willing to accept higher taxes in order to fund more services.

When considering public services, it is important to remember that creating a facility is often just the beginning of many future

\footnotetext{
${ }^{10}$ However, as university students often come disproportionately from higher income families, subsidized tuition at public universities frequently benefits the wealthy much more than the poor. This has led some economists to claim that subsidies to higher education are regressive. However, a more complete analysis that takes into account the taxes that higher income households pay to finance these subsidies suggests that the net impact of these subsidies on the income distribution is neutral or slightly progressive. See Johnson, W. (2005), "Are Public Subsidies to Higher Education Regressive?” Education Finance and Policy, vol. 1, pp. 288-315.
} 
financial obligations. For example, public services involve expenses for operations and maintenance that can be substantial. Indeed, for many government programs (for example, schools or public medical facilities) operating costs - salaries for employees, expenses for supplies, and costs of upkeep and management - far exceed those of construction, certainly if aggregated over the life of a project. Proper management also requires appropriate incentives for employees to provide good service (e.g., competitive salaries, perhaps with bonuses) and for users to make effective use of facilities - for example, through charges for water usage and fines for not returning library books. In some cases, efficiency may involve having government contract out all or part of the service to the private sector. In many countries, for example, publicprivate partnerships are used to construct facilities such power plants or toll roads, letting private parties receive tolls or charges in return for constructing and operating the facility. In some localities, private firms are used in place of government employees to collect rubbish. Indeed, private firms are sometimes used in place of government agencies as a way of avoiding "entrenched bureaucracies," since in principle it may be easier to change private contractors than to fire public employees.

Because government has its own monopoly power, it is important that public goods not become "public bads." Widespread corruption, for example, can make a public agency worse than having none at all. A corrupt court system or a highly complicated tax system can make doing business more difficult. Similarly, an inefficient public utility can impose heavy costs, or subject users to poor service. In addition, allowing a government regulatory authority to be controlled by those it is supposed to regulate can reduce competition and the provision of services to the public. Thus, it is critical that the delivery of public services meet certain standards of quality and efficiency. In practice, the quality of services varies widely, both across and within countries. $^{11}$

\footnotetext{
${ }^{11}$ For details on the World Bank's assessment of government effectiveness and governance, see its "Worldwide Governance Indicators", website https://info.worldbank.org/governance/wgi/.
} 


\subsubsection{Externalities}

Externalities - benefits or costs that accrue to third parties from the economic activities of a producer or consumer that are not reflected in the market price - represent still another area that private markets cannot handle efficiently. Consumers and producers normally have no incentive to take externalities into account when they decide what to buy or produce, because they rarely experience the effects of their activities on others. Unless third parties intervene, through regulation or by imposing penalties or providing subsidies, producers and consumers of the good or service will make their production or purchasing decisions solely on the benefits and costs to themselves. Thus, goods with negative externalities (e.g., pollutants) will be overproduced, and those with positive externalities (e.g., those generating benefits to others that the producer or consumer cannot realize) will be under-produced, relative to where the externalities are recognized and valued appropriately. As noted earlier, classic negative externalities include air and water pollution from production, traffic congestion (such as from the construction of free highways that attract too many cars during peak travel periods), and "sprawl" (outward, lowdensity growth of urban areas that destroys scenic rural areas and farmland) from unregulated building projects. Positive externalities are less well known but equally important. Examples include the social benefits from having an educated population (positive externalities from primary and secondary education) and the better environment that results from such public health programs as vaccination drives and mosquito eradication measures.

As with public goods, government is an appropriate agent to address most externalities, because it can represent the interests of third parties and use its taxing and regulatory powers to address them. Because externalities affect the costs and benefits of an activity, the most efficient way to address them is to for government to impose taxes or provide subsidies that change the price of the activity. This approach "internalizes the externalities," by embedding them in the price the consumer faces. For example, if government determines 
that the pollution generated by a manufacturing firm imposes costs equivalent to 100 Euros per metric ton, it can impose a "pollution tax" of that amount on the producer, who in turn can be expected to reflect the tax in the price of the firm's products. Likewise, government can convey the cost of congestion to others by charging peak-period tolls for highway usage (see Box 1.4 on Singapore's approach to this issue, for an example). On the positive side, the social value of literacy can be made tangible through subsidies or free tuition for primary education. Similarly, government can fund "beautification" (e.g., tree planting) programs or provide tax benefits to underwrite the cost of certain research projects.

Although in principle taxes and subsidies are the most efficient way to address externalities, in practice it may not always be possible to do so. For example, it may be hard to measure the amount of pollutants. In addition, the cost of pollution may vary from one area to another and depend on air currents and the time of the year. In the case of global warming, the risk from heat-generating activities is difficult to assess, although carbon usage can be measured. Similarly, it may be difficult to require producers to install pollution-measuring devices. In other cases, people may doubt that charges will be able to deter noxious activities.

For all of these reasons, many governments prefer to address externalities by regulation, for example, prohibiting activities with negative externalities and mandating those with positive side benefits. The problem with this approach is that it does not allow for the possibility that the public would prefer to have some goods, even with the negative externalities, than none at all. A regulatory approach, such as zoning, may restrict the number of houses per hectare as a way of limiting the need for school construction. This can make house prices very expensive. An alternate approach, levying "public service fees" on developers that will be passed onto consumers in the price of housing, allows the market to determine how much housing the public wants by having the price reflect the cost of public services that will be required, such as access to sewage and water supply lines. 
When addressing externalities, it is important that policy not constrain access to other worthwhile goods and services. For example, free public education should not prevent investment in private education. More generally, state-owned enterprises should not have an unfair advantage in competing with private producers.

\subsubsection{Merit goods}

An interesting concept closely related to the idea of externalities is the notion of merit goods. These are goods that are thought to confer strong benefits to society as a whole and thus "deserve" to be provided. Hence, a case can be made for subsidizing their creation and distribution. Typical merit goods include fine art, serious theater, opera and symphonic music, and national historical institutions, because they are seen as contributing to a society's culture. Some analysts in democratic countries would also consider "liberal education" as a merit good, because it encourages careful reading and critical thinking, which are important for the analysis of ideas in a free society. A few might add not-for-profit, independent news and cultural media networks, such as Corporation for Public Broadcasting in the United States or the BBC in the United Kingdom, since they offer non-partisan but intellectually serious information free of charge to the public.

A key question for those promoting the concept of merit goods is whether these are just a special class of goods with positive externalities. Like basic research and public health programs, merit goods are considered to benefit not just those who consume them but also others. What is arguably different is that these goods are often said to have intrinsic cultural value. In practice, merit goods often appeal mainly to an elite segment of society. Thus, one can argue whether merit goods are simply things that have positive value for a small but influential part of the population.

Because of the controversy surrounding merit goods, the case for public support requires strong factual justification. One should ask, for example, whether the activity truly benefits the public. This can 
raise a variety of issues involving public tastes. The government should think carefully about the process for determining which activities merit support. It may be important to establish certain criteria for making decisions, to ensure that minority and controversial but high-quality projects can be considered, in addition to those that a wide segment of the population considers worthwhile. One can also ask whether the public sector needs itself to supply these goods (for example, through a state-owned museum, opera company, or television network). It may be equally or more effective for the state to subsidize private providers, as is common in Singapore (through the National Council for the Arts) and the United States (through the National Endowment for the Arts). Another option is to provide vouchers to students or lowincome households, so that they find it easier to attend designated cultural activities.

\subsubsection{Addressing distributional issues}

Because markets reward those who supply highly desired goods and services, they need not produce a "just" distribution of income. Those with few marketable skills, or for whose skills there is little demand, or who happen to be competing with many others for a limited number of positions, will inevitably earn less than those whose skills are in much demand and short supply. The distribution of assets is often even more unequal, as it usually requires a fair amount of financial capital to have access to high-earning investment opportunities.

Because the so-called basic needs typically require a minimum amount of income, a case can be made for government intervention to create a social safety net for the most vulnerable, if not to adjust the distribution of income more extensively. Income can be redistributed through both tax and expenditure measures, although most experience suggests that it is easier to provide support to those with low incomes through government spending.

On the revenue side, most governments have a progressive income tax, with higher marginal rates as income increases, so that higher 
income taxpayers pay a higher share of their incomes in tax than do those with lower incomes. A few countries (e.g., Romania and Russia) have so-called flat income taxes, with only a single rate applied to taxable income. However, even these taxes can be progressive, if they exempt the bottom slab of income from tax, because the percentage of income subject to tax rises with income. Besides income taxes, countries can address the distribution of income and wealth through estate, inheritance, and gift taxes, which can impose a high tax rate on large estates or inheritances, and on large gifts to individuals, unless the deceased (or living donors) give a large share of their property to approved charitable activities. Finally, the United States provides a significant amount of support to low-income households with earnings through its Earned Income (Tax) Credit. Under this program, households with earned income (wages and salaries) can actually receive money from the government by filing a tax return if their incomes are sufficiently low and they meet certain criteria regarding citizenship and family composition.

Governments have a wide variety of expenditure programs to address distributional concerns. These include food distribution and subsidy programs for low-income households, income support and temporary employment projects for the unemployed, and income support for the disabled. Most high-income countries and many countries transitioning from central planning have government-sponsored pension programs for the elderly, and many of these provide more-thanproportionate benefits to low-income, compared to higher income, households and individuals. In many countries, government support for health and education particularly benefits lower income households, as they are more likely to use state health clinics and public schools. In addition, government subsidies for transit (bus, rail, and jitney fares) help low-income families disproportionately, since they rely more on public transportation. For the same reason, general fuel subsidies more often assist upper income households, who are more likely to own and use automobiles. More generally, to address distributional concerns, government subsidies must be targeted toward low-income households. In many low- and middle-income countries, identifying 
low-income households can be challenging, although various strategies are available to help identify and reach the poor. Targeting, however, may render benefit programs politically unpopular, particularly when powerful groups (such as government employees or rich farmers) find their interests threatened. Even in advanced economies, governments sometimes have to enact benefit programs that assist middle- and even upper income families, to secure the political support needed to aid the poor.

Programs to redistribute income, like tax measures, impose costs that must be considered. These include the cost of administering the program, such as creating offices and hiring staff, and the costs of compliance. Meeting the many requirements needed to qualify for assistance can be difficult and time consuming. In addition, many individuals feel stigmatized if they receive benefits. Accordingly, some who are eligible choose not to apply. At the same time, expenditure programs invite fraud and abuse, and governments may have to accept a certain amount of wrongdoing in order to make it simpler for those who do qualify to receive benefits. Governments must also take into account the effect that programs have on the incentives to work and save. Jobless workers may be hesitant to accept job offers if unemployment benefits are too generous (too high a percentage of the person's last wage), for example. Similarly, overly generous state pension benefits may reduce the incentives to develop private savings for retirement, although economists are divided over whether the evidence supports this claim. Finally, measures to require employers to pay a minimum wage may reduce the demand for low-skilled workers, although in some countries research suggests that current minima may be too low to have much effect on employment levels.

Assessing the impact of government programs on the distribution of income requires considering both tax and spending measures. For example, a less-than-progressive tax system, in which income and profits are taxed more lightly than consumption, may be accompanied by a large number of spending programs that assist the poor, such as food and employment subsidies, free public schools, government 
health clinics, and support for the elderly. Thus, the combined impact of tax and spending programs on households at different income levels must be assessed. Doing so is hard, because tax systems and spending programs are complex, and determining who bears the burden of different taxes and who benefits from various programs may be difficult. Two tax systems with similar tax rates but different sets of exclusions for example, one that taxes interest and capital gains, and one that does not - may have affect households very differently, because households at different income levels derive different shares of their incomes from wages and salaries, interest and dividends, and capital gains. Similarly, the distributional effect of social expenditures depends on the quality of benefits provided to households at different income levels. Thus, public education programs may appear to favor the poor. In fact, however, as noted earlier in footnote 10, middle- and upper income families benefit disproportionately if their schools receive much higher outlays per pupil, or if better services are provided to higher than to lower income households.

In practice, it may be harder for government to address distributional concerns by fostering opportunity and wealth holding than by providing minimum levels of consumption through subsidies and income transfer programs. Nevertheless, certain programs can provide greater opportunities for higher earnings. These include free and high-quality primary and secondary education, effective job training and retraining programs, public health programs and health clinics that provide effective and inexpensive health services, subsidies for pensions and homeownership, and civil rights laws that help overcome discrimination in the marketplace.

\subsubsection{Stabilization}

Macroeconomic stabilization represents still another area where government has a role to play in a market economy. It is widely acknowledged that markets are subject to a variety of shocks and can therefore experience significant fluctuations. External shocks, such as changes in weather, world interest rates, or market perceptions 
of a country's economy, can have a dramatic impact on a nation's economic growth and inflation rate. Indeed, during late 2008 and much of 2009 many developing and emerging market countries found that turbulence originating in the United States and other advanced economies adversely affected their exports, growth rates, and in some cases exchange rates. Domestic business cycles, which can reflect shifts in investment behavior or changing consumer sentiment, also affect an economy's macroeconomic performance.

Economic fluctuations can have serious repercussions for a country's citizens. Recessions typically bring not only slower or negative economic growth but also losses in household income, higher unemployment, and more business failures. Poverty rates often increase when economic growth declines. Indeed, losses are often spread unevenly, with the poor and those in specific industries affected more than others. A sharp rise in GDP that causes an economy to overheat can trigger higher inflation and, in some cases, asset bubbles that can trigger subsequent collapse when equity or real estate prices can no longer be maintained. Higher inflation has particularly adverse effects on the poor, since whatever assets they have are more likely to be in cash, and thus especially subject to the inflation tax.

Free markets have few "natural" ways to respond to economic shocks. Many developing country economies, for example, are often poorly diversified. Even small advanced economies with high ratios of trade to GDP, such as Singapore, are highly exposed to changes in the global economy. In addition, private parties have little incentive to "lean against" the prevailing market pressures. Private parties typically benefit from asset booms and overheating and are unlikely to gain from delaying investments and other projects. Similarly, private parties may have trouble judging when a depressed economy will begin to revive. Thus, there is little incentive to invest or spend aggressively while the economy looks weak.

For all of these reasons, counter-cyclical policy by government can help stabilize a nation's economy. Loosening monetary policy, by 
providing liquidity and lowering interest rates, can make investment projects more attractive and promote borrowing. Similarly, countercyclical fiscal policy, involving tax cuts and spending increases, can boost demand directly and give firms and households more after-tax income to support private investment and consumption. When inflation accelerates or an economy threatens to overheat, monetary tightening can help cool demand by raising interest rates and discouraging borrowing. Similarly, tightening fiscal policy, by raising taxes and non-tax revenues and reducing government expenditure, can decrease demand through reductions in private and government spending. Although politicians are especially fond of relaxing policies during recessions, it is important for policy also to be tightened during economic booms, so that the government has sufficient credibility for policy relaxation to boost growth and not trigger a loss in confidence that can provoke a capital outflow and sharp depreciation in the national currency. Research has shown that many developing countries lack the ability to implement expansionary fiscal policy during recessions because they have been unsuccessful at limiting expenditure during good times. ${ }^{12}$ In other words, pro-cyclical policy during booms limits the ability to implement counter-cyclical policy during slowdowns.

Although many options are available for stimulating output during recessions, the 2007-2009 economic crisis demonstrated that some policies are more effective than others at boosting demand. A 2008 study by staff at the International Monetary Fund (IMF), for example, contended that increased spending, including higher transfer payments, and tax cuts targeted on lower income households, are likely to have larger positive effects on jobs and incomes than more general tax cuts or increases in subsidies. ${ }^{13}$ A subsequent IMF staff paper argued that infrastructure projects may have the largest payoffs in

\footnotetext{
${ }^{12}$ See, for example, Ilzetzki, E., and C. A. Végh (2008), "Procyclical Fiscal Policy in Developing Countries: Truth or Fiction?” NBER Working Paper No. 14191 (Cambridge, MA: National Bureau of Economic Research).

${ }^{13}$ See Spilimbergo, A. et al. (2008), "Fiscal Policy for the Crisis," IMF Staff Position Note SPN/08/01 (Washington, DC: International Monetary Fund, December), http://www.imf. org/external/pubs/ft/spn/2008/spn0801.pdf.
} 
terms of income and jobs created for each unit of spending. ${ }^{14}$ One reason may be that such projects create a stream of expenditures for inputs that in turn lead to considerable hiring, not just for the project itself but also for firms that supply goods and services for the projects. The second highest multiplier is for transfers targeted on lowincome (borrowing-constrained) households. Cuts in labor taxes and untargeted transfers have noticeably smaller multipliers. Research also shows that expansionary fiscal policy is more powerful when supported by accommodating monetary policy. The inflationary consequences are also greater, although inflation remained subdued in many countries during 2009 and 2010.

\subsubsection{Addressing information failures: Regulation and social insurance}

Limited or asymmetric information in private markets offers still another justification for government involvement in the economy. For example, the inability of lenders to assess borrowers limits lending to lower income households, while richer households and established firms can obtain loans, some of which will prove uncollectable (nonperforming assets). Similarly, without regulation, unequal access to information can lead to a wide variety of ills in financial markets, including fraud and insider dealing. Myopia (short-sightedness) and adverse selection (the tendency of those needing coverage to be the ones to apply for it) can make it harder for private markets to make available health insurance and annuities (pensions for life). Finally, inadequate and unequal information can enable medical providers to "create demand" for their services or get patients to request medically unnecessary tests and procedures because patients lack the information to determine whether they are receiving appropriate care or whether a particular medical procedure has value or is "worth the cost." Following are examples of this general principle.

\footnotetext{
${ }^{14}$ See Freedman, C. et al. (2009), "The Case for Global Fiscal Stimulus," IMF Staff Position Note SPN/09/03 (Washington, DC: International Monetary Fund, March), http://www.imf. org/external/pubs/ft/spn/2009/spn0903.pdf.
} 


\subsubsection{Deposit insurance}

Most economists acknowledge that asymmetric information makes it hard for the private sector to provide deposit insurance, i.e., insurance that depositors will not lose their funds if a bank fails. The reason is that bank managers know their own risk profile far better than do outsiders, who have only limited information about a bank's asset portfolio. Potential insurers typically know only the information that a bank releases, usually through periodic reports. Likewise, few depositors typically know the "true" condition of their bank, unless they have inside information. For these reasons, it is hard to assess the risk that a bank might fail and, thus, price that risk before it happens. However, at least one economist has argued that it may be possible to infer such risk by requiring banks to issue subordinated debt and then looking at its "price" (i.e., the spread between interest rates on that debt and on relatively secure assets, such as short-term government securities). ${ }^{15}$

To maintain confidence, particularly after bank runs have led to bank closures, the government must intervene appropriately. Because bank failures can have serious repercussions for the rest of a nation's economy, government should regulate and supervise the activities of individual institutions. This includes a variety of measures, including standards for opening banks, rules mandating minimum capital levels and the disclosure of information to regulators, and limitations on how much of a bank's capital may be lent to any one borrower (or, perhaps, industry). In addition, because regulation and supervision cannot prevent all bank failures, a case can be made for governmentprovided deposit insurance. Because unlimited deposit insurance can create incentives for risky behavior by financial institutions, ${ }^{16}$ deposit insurance should ideally be limited in scope. Most countries provide full coverage only for small depositors, as they cannot be expected to be aware of the condition of different financial institutions. Large

\footnotetext{
${ }^{15}$ See, for example, Calomiris, C. W. (1989). "Deposit Insurance: Lessons from the Record," Economic Perspectives (May), Federal Reserve Bank of Chicago, pp. 10-30.

${ }^{16}$ Ibid.
} 
depositors should receive only partial coverage for their deposits. This will give them an incentive to police the behavior of individual banks and remove their funds if they consider a particular institution unsafe.

\subsubsection{Pensions}

Individuals are often shortsighted when it comes to providing for their old age. Young adults can have difficulty envisioning that they will eventually reach an age when it is difficult to continue working and earning an income. Yet, experience shows that aging is inevitable, and that declining health makes it hard for people to anticipate remaining in the workforce. Thus, government can play a role by requiring individuals to set aside funds for retirement, whether through mandatory savings programs or through state pension programs that impose taxes to finance retirement benefits. Each approach has advantages and disadvantages (see Chapter 12 for discussion), and current recommendations from the World Bank suggest that countries develop multiple ways of providing support for the elderly. ${ }^{17}$ A potential advantage of a government pension program is that benefits can be skewed toward lower income households, who may find it especially hard to accumulate savings.

To be sure, any pension program poses potential costs. For example, a government-provided pension regime may discourage private retirement savings, although the empirical research on this issue is inconclusive. In addition, a pay-as-you-go pension program, in which current workers are taxed to support benefits for the elderly, can impose a heavy burden on future generations in a country with an aging population. The reason is that, over time, the number of workers per retiree will decline, requiring either higher taxes, lower benefits, or an increase in the retirement age to keep the system solvent. Many

\footnotetext{
${ }^{17}$ See Holtzmann, R., and R. Hinz (2005), Old Age Income Support in the 21st Century (Washington: World Bank), http://siteresources.worldbank.org/INTPENSIONS/Resources/ Old_Age_Inc_Supp_Full_En.pdf.
} 
advanced economies face serious budget problems because they have pay-as-you-go pension systems, and the problems are particularly acute in Germany, Italy, and Japan. ${ }^{18}$

\subsubsection{Health care}

Still another area where asymmetric information helps justify government involvement is health care. Because consumers rarely know what treatments they need and have difficulty assessing the accuracy of what physicians recommend, they can be persuaded to accept more care than they need, or unnecessarily costly care - what is sometimes termed "supplier-induced care." It is especially hard for consumers to shop for treatment or assess a physician's recommendation when care is needed immediately. Even if decisions can be deferred, requesting a "second opinion" may leave the consumer uncertain as to which recommendation is correct.

In theory, consumers may find it easier to choose providers when they are well than when ill. Even then, however, making an informed choice can be difficult. Individuals may have heard of certain physicians or practices by word of mouth or reputation, and the comments may not be what doctors would offer if asked in confidence. Sometimes, popular magazines publish articles listing physicians that other doctors would recommend. However, verifying the comments is difficult. Moreover, in large markets, it can be very hard identifying the most skilled physicians and specialists.

The private market for health insurance, similarly, may work less than optimally. Insurers may find that those seeking health insurance are more likely to need coverage than those who do not - an example of what economists call adverse selection. As a result, health insurance may be relatively expensive, discouraging younger and healthier people from applying. Insurers can try to reduce adverse

\footnotetext{
${ }^{18}$ See Chand, S. K., and A. Jaeger (2000), Aging Populations and Public Pension Schemes, Occasional Paper No. 147 (Washington: International Monetary Fund).
} 
selection by restricting benefits - for example, denying coverage for the so-called "preexisting conditions." In this case, however, those needing insurance cannot get it and must instead pay out of pocket for care. Limiting the ability of insurers to deny such coverage was a key objective in the Patient Protection and Affordable Care Act (Pub. Law 111-152) approved in United States in 2010.

Government programs can address many of the shortcomings of private health care markets. For example, governmental organizations can review the care given by different medical providers and publish information about relative costs and rates of success with different treatments or types of care. Similarly, governments can encourage cost-saving innovations that private markets have not undertaken for example, computerizing medical records - via subsidies and, if necessary, regulation. Governments can also create "insurance exchanges," to facilitate the comparison of insurance policies and promote competition among insurers. ${ }^{19}$ In addition, governments can also offer health insurance themselves, addressing the adverse selection problem by offering coverage to the community at large or creating large pools of individuals, so that the costs of those needing care can be spread across the population. Such coverage can be offered at cost to those unable to buy private health insurance, or at highly subsidized prices in the case of low-income households.

Government involvement in health care can create costs as well as benefits. Regulation - for example, overseeing physician behavior or mandating that certain procedures be followed - imposes burdens that can raise costs. In addition, subsidized health care or health insurance adds to the government's budget, requiring higher taxes, lower spending elsewhere, or higher public debt. In addition, providing health insurance can increase demand unless coverage is well structured, because patients will no longer face the full cost of care.

\footnotetext{
${ }^{19}$ Blumberg, L. (2009), "Improving Health Insurance Markets and Promoting Competition under Health Care Reform," Committee on Ways and Means, U.S. House of Representatives (April 22), http://www.urban.org/uploadedpdf/901246_improving $\{\backslash \%\} 20$ healthinsurance. pdf.
} 
This can make patients less sensitive to cost comparisons and encourage physicians to recommend unnecessary or unduly expensive care. It can also create moral hazard, to the extent that patients, knowing that they have insurance, are less careful - for example, not practicing oral hygiene or not being as careful about activities that increase the risk of heart disease. Moreover, health insurance can inflate the demand for health care generally, encouraging consumers to spend more for medical services than they might otherwise. The reason is that it can be very difficult disputing the value of medical treatments that offer some benefit, even if they are very costly. Thus, governments sometimes find it necessary to impose restrictions - for example, limiting insurance to well-established remedies and screening, rather than experimental treatments whose success remains to be validated. ${ }^{20}$

For these and other reasons, such as the goal of ensuring access to health care for all citizens, governments in most economies have intervened in the health care market, providing insurance, financing, and health care facilities. The specific combinations vary from country to country. The United Kingdom, for example, has created its own National Health Service, which provides a wide range of care at public hospitals and medical facilities. Canada's health care system provides full coverage for a broad array of services provided by private physicians. In France, public insurance covers $70-80 \%$ of all medical costs; most persons buy supplementary insurance, which covers nearly all the remaining charges. The Ministry of Health establishes set budgets and regulates many aspects of care, including prices for procedures and pharmaceuticals. ${ }^{21}$ In Singapore, the government provides funding for public hospitals and health clinics and requires that a portion of each person's Central Provident Fund contributions be used for their

\footnotetext{
${ }^{20}$ For further discussion of these issues, see Hsiao, W., and P. Heller (2007), "What Macroeconomists Should Know about Health Care Policy," Working Paper No. 07/13 (Washington, DC: International Monetary Fund, January), http://www.imf.org/external/pubs/ft/wp/ 2007/wp0713.pdf.

${ }^{21}$ Carroll, A. E., and A. Frakt (2017), "The Best Health Care System in the World: Which One Would You Pick?” New York Times, September 18, https://www.nytimes.com/interactive/ 2017/09/18/upshot/best-health-care-system-country-bracket.html.
} 
own Medisave account, which can be used to pay for approved health insurance premiums, hospital care, and certain types of outpatient and long-term care. In the United States, the federal government provides care directly to veterans at government-operated veterans' hospitals, offers hospitalization insurance and voluntary medical and drug insurance (at a cost) to the elderly, funds (with state participation) medical insurance for the poor through Medicaid, and supports medical research. It also supports an extensive system of privately supplied insurance coverage through tax subsidies and the organization of medical exchanges (some provided by the states) to facilitate the sale of private health insurance for those not offered insurance by their employers.

\subsection{Summary}

Even in a well-functioning market economy, government has a clear role to play in providing goods and services that markets cannot be expected to make available in sufficient quantities. Government also supports the "social contract" by establishing the framework in which markets can operate. This framework includes creating and protecting property rights, establishing rights for minority as well as majority shareholders in private firms, promoting competition in markets, and creating institutions that allow the peaceful resolution of commercial disputes. Government also plays a role in establishing vital "non-economic" rights, such as protection from discrimination and access to key sources of opportunity, such as primary and secondary education and reasonable health care services. In addition, government is needed to provide public goods, address externalities, and handle cases of natural monopoly, all examples of classic "market failure." Government is also essential to address the distributional inequities that result from the working of private markets; to create and apply policies that can help stabilize output and prices; and to provide financial sector regulation. Together, these activities help make the outcomes of the market politically acceptable, thereby facilitating the acceptance of private markets as the main means for allocating goods and services. 
Government action comes at a cost, however. Regulations designed to address market failures impose burdens on market participants. Similarly, the taxes needed to fund public goods, regulation, stabilization policies, and redistribution reduce the returns to work, saving, and investment, potentially diminishing private sector activity unless the government services provided offset these negative effects. To minimize these costs, policymakers should think dynamically, recognizing that today's solutions can create new problems for an economy. For example, the ability to use fiscal policy to stabilize output in a recession may also make government a source of inflation. Thus, policy responses should be adaptable, and government programs should be capable of modification or elimination if changing circumstances require new approaches. Many policy variants, including options ranging from nearmarket to government provision, can be developed to meet the need for public goods or the supply of services characterized by natural monopoly. Thus, governments should consider the many options available when deciding how to perform their role in doing what markets cannot be expected to do well.

\section{Box 1.1: Is Education a Public Good?}

Periodically, the question arises whether education is a public good. Primary and secondary education provide substantial benefits, not only to students and their families but also to the society in general. The general populace benefits from having a citizenry able to read and write and knowledgeable about basic rules for human interaction, skills imparted during primary school. Likewise, the economy benefits generally from having a population with the basic skills needed for employment and knowledgeable about the national history and culture, skills that secondary school provides. Because it is easy to exclude individuals from school and because resources provided to some students preclude their provision to others, it is difficult to see education as satisfying the tests of nonexcludability and non-rivalrous consumption that normally apply 


\section{Box 1.1: (Continued)}

to public goods. However, the strong positive externalities from primary and secondary schooling and the value of having children at all income levels acquire these skills explain why most governments provide primary and secondary education to all citizens, usually at little or no cost.

\section{Box 1.2: The Free Rider Problem}

An issue that inevitably arises with the provision of public goods is the "free rider" problem. Because public goods are available to everyone when available to anyone, there is a strong incentive for individuals to avoid contributing to their cost. Accordingly, people are encouraged to become "free riders" - those gaining benefits without paying for them. If free riding becomes too prevalent, it will be hard to finance a good or service.

Free riding occurs in many settings. Classic examples include the following:

1. The tragedy of the commons: Government or a kind benefactor provides a good or service that needs maintenance. Unless maintenance can be enforced, or people are required to pay for it, the good or service will deteriorate. A good example is the recent provision of very inexpensive bicycles in several European cities, where many people have stolen or damaged the bicycles with impunity, thereby challenging the viability of the service.

2. People "holding up an agreement" for pay: When unanimous consent is needed for an agreement, the last few individuals can force the remainder to pay a very high price for their agreement, much more than their share of any benefits from its implementation.

3. Negotiating passage of a bill in a parliament: Members of parliament who are not that interested in a bill's main issues can use it as a way to get approval of a side issue that interests them. 


\section{Box 1.3: Infrastructure Spending in the United States}

In 2017, the IMF estimated that the United States spent less than $2.5 \%$ of GDP annually on infrastructure from 1990 through 2015, and only $1.6 \%$ in $2015 .^{22}$ The OECD reported a noticeably smaller figure of about $0.6 \%$ for 2015 , less than the estimated outlays in Japan and the United Kingdom (0.9\%) and France $(0.8 \%) .{ }^{23}$ The World Economic Forum's Global Competitiveness Report for 2018 ranked the United States ninth in infrastructure, behind Singapore, Hong Kong SAR, Switzerland, Netherlands, Japan, Republic of Korea, Germany, and France. ${ }^{24}$ In 2017 , the American Society of Civil Engineers (ASCE) gave United States infrastructure an overall grade of $\mathrm{D}+$, with grades ranging from $\mathrm{B}$ for rail to $\mathrm{D}-$ for transit. The ASCE estimated that US\$2.0 trillion would be needed over a 10 -year period to fill the shortfall in infrastructure, corresponding to raising expenditure to between $2.5 \%$ and $3.5 \%$ of GDP annually. ${ }^{25}$

\section{Box 1.4: Singapore's Approach to Addressing Traffic Congestion}

Singapore offers an interesting example of how to address traffic congestion: its "electronic road pricing" or ERP system. This small island country has erected overhead gantries at the entrance to many potentially congested areas. All vehicles are required to have installed on the dashboard a small device that holds an electronic cash card, and a vehicle that passes under a gantry incurs a toll that is deducted from the balance on the card. The amount of

\footnotetext{
${ }^{22}$ International Monetary Fund (2017), United States: 2017 Article IV Consultation - Press Release; Staff Report, Washington, July, p. 27.

${ }^{23}$ OECD Data, "Infrastructure Investment," https://data.oecd.org/transport/ infrastructureinvestment.htm.

${ }^{24}$ World Economic Forum (2018), Global Competitiveness Report 2018.

${ }^{25}$ American Society of Civil Engineers (2017), “2017 Infrastructure Report Card,” https:// www.infrastructurereportcard.org/.
} 


\section{Box 1.4: (Continued)}

the toll depends on the location, time of day, and type of vehicle. For example, a car pays a modest toll when entering a downtown area during a relatively uncongested part of the workday; a much higher toll during rush hour; and no toll on Sundays, when traffic is normally very low. Tolls are typically higher for larger vehicles (e.g., trucks and private busses) than smaller ones (e.g., cars and motorcycles). Taxis also pay the tolls, which are then passed on to passengers. From time to time, Singapore adjusts the level of tolls, to reflect changes in driving patters. Although the ERP system does not eliminate congestion, at least one study claims that it has reduced it. ${ }^{26}$

In 2003, London, the British capital, adopted a similar system, the London Congestion Charge, in which vehicles pay a flat toll of 8 pounds when entering the central business district. Despite much grumbling, studies suggest that it, too, has reduced congestion in the central business district. ${ }^{27}$

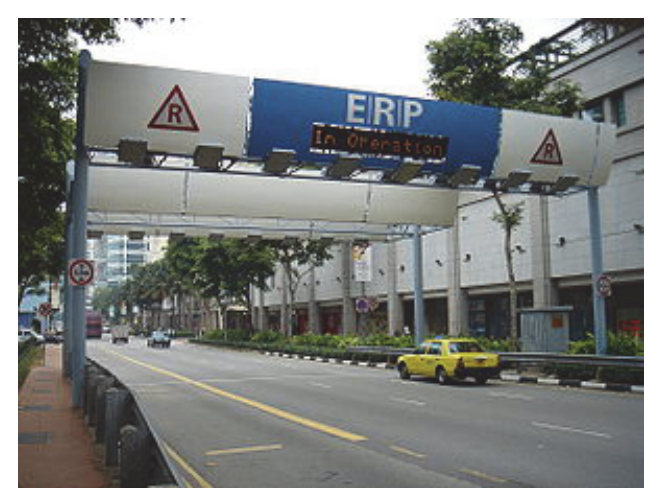

\footnotetext{
${ }^{26}$ See Chin, Kiang Kong (2002), "Road Pricing - Singapore's Experience," Singapore Land Transport Authority, http://www.imprint-eu.org/public/Papers/IMPRINT3_chin.pdf.

${ }^{27}$ See Transport for London (2003), "Congestion Charging Six Months On," http://web. archive.org/web/20060515194436/ http://www.tfl.gov.uk/tfl/downloads/pdf/congestioncharging/cc-6monthson.pdf.
} 